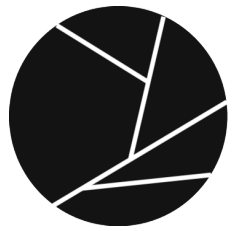

VISUAL SPACES OF CHANGE: DESIGNING INTERIORITY

SHELTER, SHAPE, PLACE, ATMOSPHERE

ISSN: 2183-8976 [PRINT] 2183-9468 [ONLINE]

Volume 5, Issue 1| Publication year: 2020

DOI 10.24840/2183-8976_2020-0005_0001_8

(c) SCOPIO EDITIONS

HOMEPAGE:

\title{
Des yeux qui ne voient pas *
}

\section{by António Choupina}

I must confess that - due to a broken foot - my enchantment with nature was somewhat faded. Staring at these photographs became an almost cathartic experience, serenity washing over in a dream, renewing a passion for the universe that created architecture and that, in turn, is recreated by it. If the Boa Nova Tea House were like Saramago's stone raft, adrift in a vast ocean, then the Serralves Museum would be like one of Cesário Verde's bucolic poems, bathed in idyllic foliage.

From the very first page, one discovers the building romantically dressed in seasonal vegetation, enveloped in a curtain of greenery, which drapes leaves as floating water lilies and droplets of rain. Distant windows seem to emerge beyond the sumptuous filter, manipulating a type of picturesque nostalgia: the primitive longing for a Garden of Eden or the simple magic of a child playing outside.

Having planted an oak tree in Serralves, this interpretation might be biased by my own boyish recollections or, perhaps, the landscape architect was just prone to episodes of refined apophenia. João Gomes da Silva was invited by Álvaro Siza to help mediate the relationship with Jacques Gréber's 1932 designs, supposedly inspired by the geometries of Versailles.

When Siza's Alhambra project was exhibited here, in 2017, I pointed out that Gréber's octagons and waterlines were connected to Granada - like those of Luis Barragán or Louis Kahn. In fact, 
all of Serralves can be viewed as a modern-day Alhambra and not because of its embellished gardens, protected by a stone wall, but because of its sequencing of spaces, of light and shade.

A luminous field is revealed upon arrival, framed by the mountainous profile of the auditorium, whose curvilinear elevation ambiguously approaches the gallery's obliquely cantilevered sunroof. A gravel courtyard follows suit, more intimately embracing a loquat tree and compressing half-light into vestibules. The limestone foyer might then be understood as a glass-covered cloister and, finally, its axis climaxes on the grassy southeast courtyard, between the two wings of the museum. 
A cubistic juxtaposing of volumes along these courtyards, overlaid longitudinally above the thalweg of the valley, manages to render this large container virtually imperceptible, cropped continuously by planes and treetops throughout a sixteen-meter geographic plunge. It's selfeffacing to an unheard of degree among 20th century institutions.

Only at the end does the museum fully take form, turning into a sort of white citadel that vanquishes its moat with a drawbridge, enacting all kinds of paradoxical mannerisms: contact through detachment, weightlessness through heaviness, asymmetry through axiality, et cetera. The bridge is a sculpture, especially now that one can no longer cross it - replaced by a crystal-shaped gift shop as gateway to the park.

Nature took charge, covering the ramp in a spontaneous pergola of branches, hiding the restaurant's once naked fenêtre en longueur. I remember it bareboned in 1999. It was my favorite moment and, for that reason, it's one of my favorite images by Mark Durden and João Leal. I could also mention a synaesthesia of silhouettes in shadow puppetry, while leaves rustled in melodic rhythm, or the emerald-green bushes, sucked inward in forced perspective and reflected back, as glassy palimpsests of themselves.

However, my most beloved photograph is the staff entrance. No, it's not the curved staircase of the $\mathbf{2 0 1 9}$ Cinema House, signaling the Art Deco tower of Marques da Silva's original villa. The future is the glade and a new museum wing, proposed by Álvaro Siza, which would bring deserved prominence to this unseen back wall, to its span, to its administrative courtyard, to its hierarchy of proportion and to its will vegetation - in the vein of Van Gogh's "Undergrowth with Two Figures".

The swirling tree bark of the Serralves Foundation is never-ending. Siza constantly awakens other sides of its reality, by skewing or deepening old and new viewpoints. "I'm sure that when Le Corbusier - himself a photographer, like Picasso, like Brancusi - said «des yeux qui ne voient pas», he thought, by opposition, in the multiplied capacity of seeing through a photographer's cultivated eye." **

\footnotetext{
* "Eyes that do not see" was published by Le Corbusier, in 1923, as part of "Vers une architecture".

** Álvaro Siza, in "L'Esperienza dei Luogui" exhibition catalogue. Edit.: Centro Cultural de Belém. 1997
} 


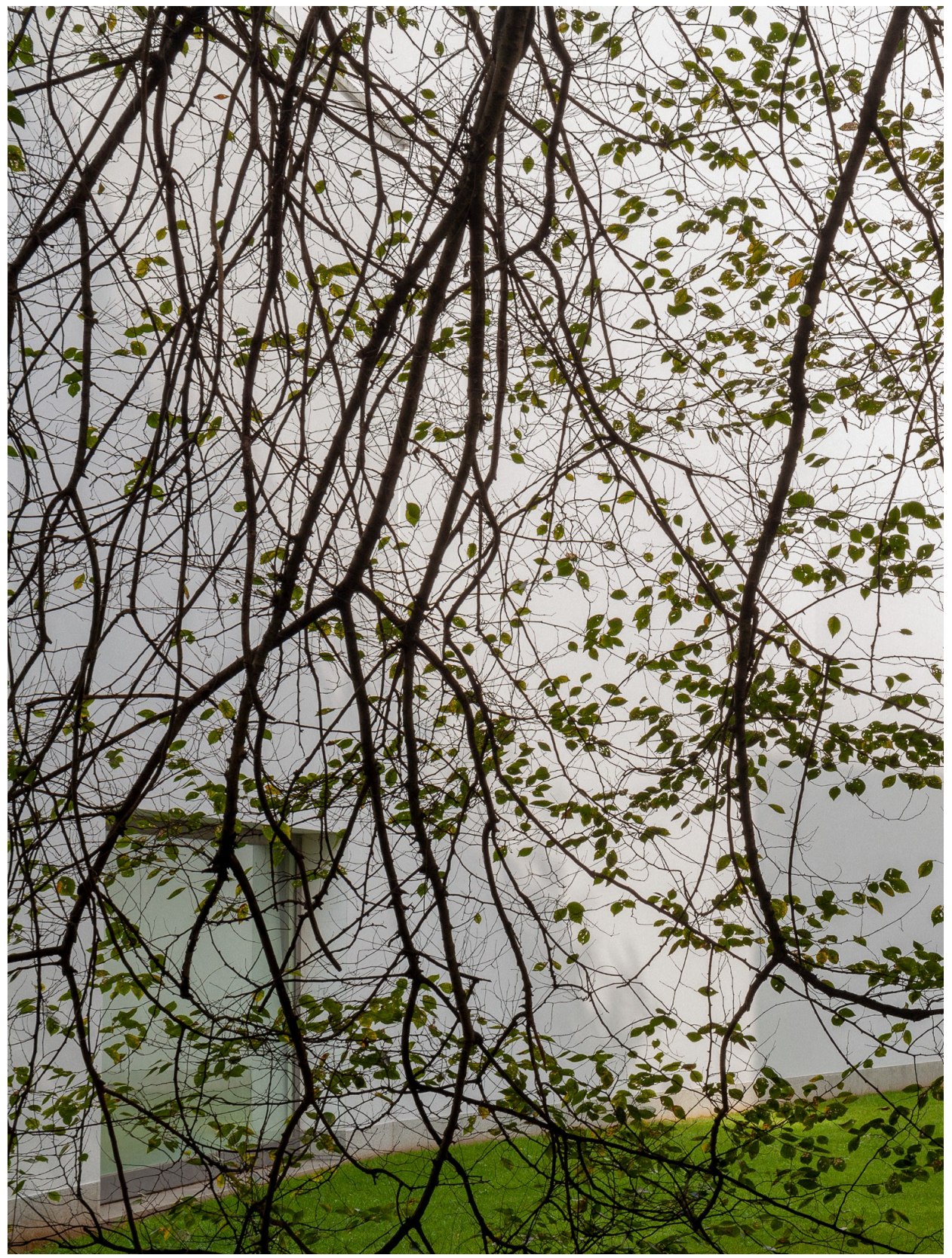



1.

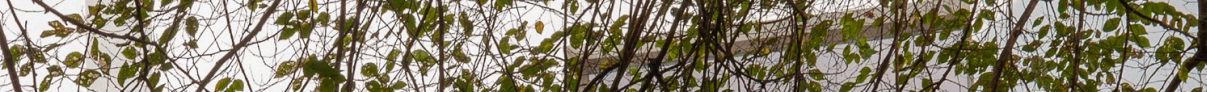
(1) a.t. (2, - $-3.1 \%$ $(1,2 \times 3)$

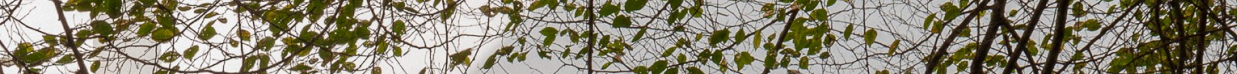

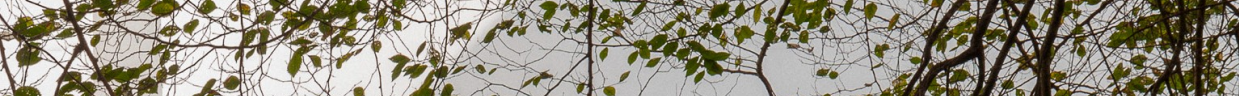

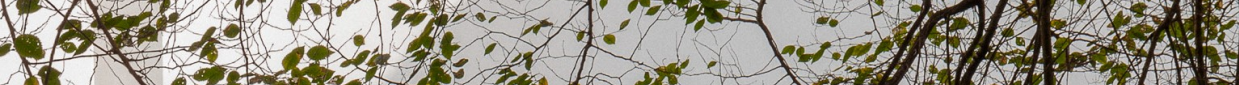

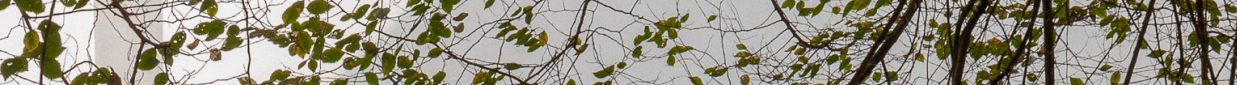

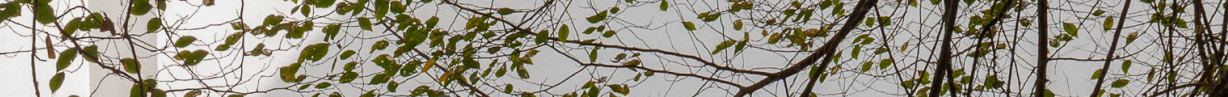

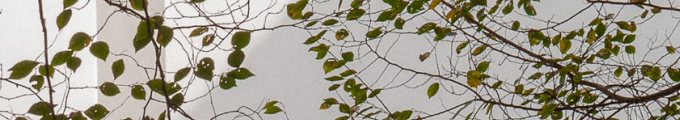

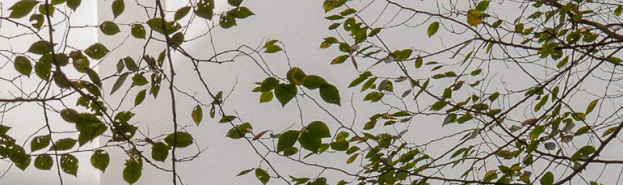

- n 